\title{
Introduction of mutant $p 53$ into a wild-type p53-expressing glioma cell line confers sensitivity to Ad-p53-induced apoptosis ${ }^{1}$
}

\author{
Julie A. Cerrato, W.K. Alfred Yung, and Ta-Jen Liu² \\ Department of Neuro-Oncology, The University of Texas M.D. Anderson Cancer Center, Houston, Texas 77030
}

Transient expression of the tumor suppressor gene $p 53$ via adenoviral-mediated gene transfer induces apoptosis in glioma cells expressing mutant $\mathrm{p} 53$, while causing cell cycle arrest in cells with wild-type $p 53$. To determine whether a change in $p 53$ status of a wild-type $p 53$ expressing cell line such as U-87 MG would alter its apoptotic resistant phenotype in response to $\mathrm{Ad}-p 53$ infection, we generated cell lines U-87-175.4 and U-87175.13 via retroviral-mediated gene transfer of the $p 53$ $(175 \mathrm{H})$ mutant into the U-87 MG parental line. Control cell lines U-87-Lux.6 and U-87-Lux.8 were also generated and express the reporter gene luciferase. Both U-87175.4 and U-87-175.13, but not control cell lines, exhibited morphology characteristic of apoptosis after Ad-p53 infection. Furthermore, expression of other $p 53$ mutants (248W, 273H) in U-87 MG also sensitized cells to Adp53-induced apoptosis. Apoptosis was confirmed by TUNEL and cell cycle analysis. Several $p 53$ response genes were examined in cells infected with Ad-p53, and among these, BCL2, $p 21^{\text {WAF1/CIP1 }}$, CPP32/caspase 3, and $P A R P$ showed differences in expression between U87-175 and U87-Lux cell lines. Taken together, our data demonstrate that the introduction of $p 53$ mutants in U-87 MG

Received 17 July 2000, accepted 2 November 2000.

${ }^{1}$ Supported in part by institutional start-up funds and the Physician Referral Service Executive Council Award from M.D. Anderson Cancer Center, and National Institutes of Health Grants CA-51148 and CA55261.

${ }^{2}$ Address correspondence and reprint requests to Ta-Jen Liu, Box 100, Department of Neuro-Oncology, The University of Texas M.D. Anderson Cancer Center, 1515 Holcombe Blvd., Houston, TX 77030.

${ }^{3} \mathrm{Abbreviations}$ used are as follows: $\mathrm{Ad} \Delta \mathrm{E} 1$, replication defective adenovirus; Ad-p53, wild-type p53 adenovirus; MOI, multiplicity of infection; PBS, phosphate-buffered saline; TUNEL, terminal deoxynucleotidyl transferase-mediated dUTP-biotin nick-end labeling. promotes an apoptotic response in association with adenoviral-mediated wild-type $p 53$ gene transfer. These results underscore the importance of glioma $p 53$ genotype for predicting tumor response to $p 53$-based gene therapy. Neuro-Oncology 3, 113-122, 2001 (Posted to NeuroOncology [serial online], Doc. 00-043, February 20, 2001. URL <neuro-oncology.mc.duke.edu>)

The $p 53$ tumor suppressor gene is a nuclear phosphoprotein that transcriptionally regulates the expression of a number of target genes including $p 21^{\text {WAF1/CIP1 }}$ (el-Deiry et al., 1993), GADD45 (Hollander et al., 1993), BAX (Miyashita and Reed, 1995), and FAS/APO1 (OwenSchaub et al., 1995). In normal cells, the p53 protein is expressed at low levels and has a short half-life due to a rapid turnover rate mediated by ubiquitination and proteolysis. Upon exposure to a number of stressful stimuli, including DNA-damaging agents and hypoxia (Carmeliet et al., 1998), the p53 protein is stabilized and, in turn, regulates biological functions including cell cycle arrest (elDeiry et al., 1994), apoptosis (Liu et al., 1995), senescence (Sugrue et al., 1997), differentiation, and antiangiogenesis (Dameron et al., 1994). However, p53 function is often deregulated or impaired after the occurrence of mutations or deletions resulting from neoplastic transformation.

Astrocytomas and glioblastomas are the most frequently occurring CNS tumors of neuro-epithelial origin and the most challenging brain tumors to treat. In more than $30 \%$ of astrocytomas, mutations exist in the $p 53$ tumor suppressor gene whereby inactivation occurs through missense mutation or loss of heterozygosity (Van Meir et al., 1994). The $p 53$ gene (located on chromosome 17) is frequently associated with the loss of 1 allele in malignant gliomas, although a large number of malignant gliomas have no $p 53$ mutations (Fults et al., 1992). Some of the latter tumors have an amplified MDM2 
(murine double minute 2) gene (He et al., 1994) that suppresses $p 53$ gene activity. Both the loss of normal $p 53$ function and the acquisition of oncogenic functions by mutant $\mathrm{p} 53$ proteins may contribute to tumorigenesis.

Consistent with the definition of a tumor suppressor gene, the reintroduction of wild-type $p 53$ into many tumor cell lines, including gliomas, results in the activation of cell cycle arrest and/or apoptosis (Gomez-Manzano et al., 1996). The general conclusion from these studies is that the introduction of wild-type $p 53$ into neoplastic cells in vitro is lethal in most cases, so long as the cells are $p 53^{\text {mut }}$ or $p 53^{\text {null }}$. However, the reintroduction of wild-type $p 53$ into $p 53^{w t}$ tumor cells results solely in cell cycle arrest (Nielsen and Maneval, 1998). The molecular mechanisms underlying the differential response of these cell lines to exogenous $p 53$ remains unclear.

The current phase I clinical trial using $\mathrm{Ad}-\mathrm{p} 53^{3}$ to treat glioma is based on laboratory studies in which Adp53 efficiently suppresses the growth of tumor cells bearing a mutant $p 53$ both in vitro and in vivo (Gomez-Manzano et al., 1996). However, given the fact that most tumors are heterogeneous in nature, and the ability of exogenous $p 53$ to affect only tumor cells harboring mutant $p 53$, it is conceivable that the sole use of Ad-p53 for the treatment for cancer patients would not yield a satisfactory outcome. Under this notion, it is imperative to investigate the mechanism whereby cells with different $p 53$ gene status respond differently to Ad-p53.

Introduction of mutant $p 53(175 \mathrm{H})$ into the wild-type p53 glioblastoma cell line U-87 MG confers a dominant negative phenotype (Yount et al., 1996). When synchronized cells were irradiated in $G_{1}$, the control cell line (U87-Lux.8) expressing functional $p 53$ was twice as sensitive to radiation as the isogenic dominant negative mutant derivative (U87-175.4), in which $p 53$ was inactivated. Here we have investigated the apoptotic response of the U87-175 cell lines as well as other isogenic cell lines expressing different mutant $p 53$ genes $(248 \mathrm{~W}$ or $273 \mathrm{H})$ after adenoviral-mediated gene transfer of wildtype $p 53$. Our findings demonstrate that the presence of mutant $p 53$ is a major determinant in whether cells are responsive to Ad-p53 induced apoptosis.

\section{Materials and Methods}

\section{Cell Lines}

Both U87-Lux.8 and U87-175.4 were derived from the human glioblastoma cell line U-87 MG after recombinant retroviral infection and clonal selection in 400 $\mu \mathrm{g} / \mathrm{ml}$ of G418 selection media. Both U87-Lux.8 and U87-175.4 cell lines were generated by infection of U-87 MG with recombinant retrovirus containing a mutant p53 cDNA in codon $175 \mathrm{H}$ or a luciferase reporter gene, respectively (Hsiao et al., 1994). Isogenic cell lines of U87 MG containing other $p 53$ mutants $(248 \mathrm{~W}$ or $273 \mathrm{H})$ (Zhang et al., 1993) were generated by stable transfection with either $\mathrm{pRc} / \mathrm{CMV}-248 \mathrm{~W}$ or $\mathrm{pRc} / \mathrm{CMV}-273 \mathrm{H}$ expression vector. After G418 selection, colonies were isolated and the expression of $p 53$ was assessed by Western blot analysis. Control cell lines were generated by transfection of only the expression vector $\mathrm{pRc} / \mathrm{CMV}$ into
U-87 MG and similarly selected. Cells were cultured in Dulbecco's modified Eagle's/F12 medium (1:1, vol/vol) containing $10 \%$ fetal bovine serum supplemented with penicillin and streptomycin. Cells were maintained in a humidified atmosphere containing $5.0 \% \mathrm{CO}_{2}$ at $37^{\circ} \mathrm{C}$.

\section{Generation of Recombinant Adenovirus and Conditions of Infection}

The recombinant $p 53$ adenovirus (Ad-p53) and Ad- $\beta$ gal contain the cytomegalovirus promoter, wild-type $p 53$ cDNA or $\beta$-galactosidase, and SV40 polyadenylation signal in a mini-gene cassette inserted into the E1-deleted region of modified adenovirus type 5 (Ad5) (Liu et al., 1995). Replication-defective adenovirus Ad $\Delta \mathrm{E} 1$ (provided by Dr. Bingliang Fang (Department of Thoracic and Cardiovascular Surgery, M.D. Anderson Cancer Center, Houston, Tex.) was generated by cotransfecting the pXCJL-1 and pJM 17 plasmids Ad-p53 and $\operatorname{Ad} \Delta \mathrm{E} 1$ (Liu et al., 1999). The cell lines were infected as previously reported (Gomez-Manzano et al., 1996), and culture medium was used for mock infection. Infection was performed at 100 MOI for $1 \mathrm{~h}$ of incubation at $37^{\circ} \mathrm{C}$ with constant shaking.

\section{Western Blot Analysis and Antibodies}

Total cell lysates were prepared at various time points from mock-infected cells and cells infected with Ad-p53 or $\operatorname{Ad} \Delta \mathrm{E} 1$ virus. Cell pellets were washed in $\mathrm{PBS}$ and resuspended with Lysis buffer $(150 \mathrm{mM} \mathrm{NaCl}, 1 \%$ Triton $\mathrm{X}-100,1.0 \%$ sodium deoxycholate, $0.1 \%$ sodium dodecyl sulfate, $20 \mathrm{mM}$ EDTA, and $50 \mathrm{mM}$ Tris, $\mathrm{pH}$ 7.4) for $30 \mathrm{~min}$ on ice. Protein concentrations were determined using the Bradford protein assay (Bio-Rad Laboratories, Richmond, Calif.). Fifty micrograms of protein were subjected to gel electrophoresis and separated on a $10 \%$ sodium dodecyl sulfate-polyacrylamide gel electrophoresis. After separation, proteins were transferred to a nitrocellulose membrane and blotted with either anti-p53 DO-I, Ab-3 (pAb240; Oncogene Science, Mineola, N.Y.), anti-p21 $1^{\text {WAF1/CIP1 }}$ (Santa Cruz Biotechnology,

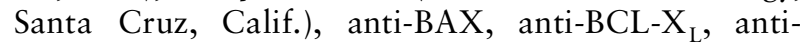
MDM2, anti-BCL2, or anti-pro-CPP32 antibodies (Santa Cruz Biotechnology). For PARP detection, cells were sonicated on ice for $20 \mathrm{~s}$ and stored in $-20^{\circ} \mathrm{C}$. Lysates were incubated at $65^{\circ} \mathrm{C}$ for $15 \mathrm{~min}$ prior to gel loading. One hundred micrograms of protein was subjected to $10 \%$ sodium dodecyl sulfate-polyacrylamide gel analysis and was probed with an anti-PARP C2-10 monoclonal antibody at a dilution of 1:2000. Equal loading was determined by using an antiactin antibody (Amersham Corp., Arlington Heights, Ill.).

\section{Cell Viability Assay}

Cell cultures were harvested with $0.05 \%$ trypsin and seeded in triplicate at $1 \times 10^{5}$ in 6-well culture plates for $24 \mathrm{~h}$ prior to viral infection. Cells were infected with Adp53 or $\mathrm{Ad} \Delta \mathrm{E} 1$ at $100 \mathrm{MOI}$. Culture medium was used for mock infection. Cell populations were counted at various time points after infection. Cell viability was assessed by trypan blue $(0.1 \%)$ exclusion. 


\section{Caspase Activity Assay}

Cells $\left(1.0-2.0 \times 10^{6}\right)$ were scraped, washed in PBS, and lysed using 25-50 $\mu \mathrm{l}$ of cell lysis buffer (RandD Systems, Minneapolis, Minn.) to obtain cell lysates. Each enzymatic reaction was performed using $100 \mu \mathrm{g}$ total protein and was carried out in a flat-bottom 96-well plate. Five microliters of the caspase fluorogenic substrate was added to each reaction and samples were incubated at $37^{\circ} \mathrm{C}$ for 1 to $2 \mathrm{~h}$. Fluorescence was measured on a microplate reader using a filter that allowed a light excitation at $400 \mathrm{~nm}$ and light collection at $505 \mathrm{~nm}$ (Perkin Elmer, Norwalk, Conn.). Substrate for each caspase is as follows: caspase-1, WEHD-AFC; caspase-2, VDVADAFC; and caspase-3, DEVD-AFC.

\section{Flow Cytometry}

Cells were infected with 100 MOI of Ad-p53 or replication-defective virus $\operatorname{Ad} \Delta \mathrm{E} 1$. They were harvested at $48 \mathrm{~h}$ and $96 \mathrm{~h}$ postinfection, and pellets were washed 3 times in PBS and fixed with $70 \%$ ethanol for $24 \mathrm{~h}$ at $-20 \mathrm{C}^{\circ}$. The cells were then stained with a solution of PBS containing $1.0 \%$ propidium iodide for $20 \mathrm{~min}$ at $37^{\circ} \mathrm{C}$ to measure DNA content. Flow cytometry of cell cycle profiles was performed on an EPICS (I) Profile Analyzer (Coulter Corp., Hialeah, Fla.).

\section{TUNEL Assay}

The assay was performed according to the manufacturer's procedure (Phoenix Flow Systems, San Diego, Calif.). Briefly, after fixation and washing, cells were resuspended in $50 \mu \mathrm{l}$ of TdT buffer containing $0.2 \mathrm{M}$ sodium cacodylate (pH 7.0), $2.5 \mathrm{mM}$ Tris-HCl, $2.5 \mathrm{mM} \mathrm{CoCl}_{2}$ (Sigma Chemical Company, St. Louis, Mo.), 0.1 mM DTT (Sigma), 0.25 $\mathrm{mg} / \mathrm{ml}$ bovine serum albumin (Sigma), 5 units of terminal transferase (Boehringer Mannheim Biochemicals, Indianapolis, Ind.), and $0.5 \mathrm{nmol}$ biotin-16-dUTP along with dATP, dGTP, and dCTP at a concentration of $20 \mu \mathrm{M}$. Controls were prepared by incubating a separate aliquot of each test sample without dUTP. The cells were incubated in the solution at $37^{\circ} \mathrm{C}$ for $30 \mathrm{~min}$, rinsed in PBS, and resuspended in $100 \mu \mathrm{l}$ fluorescein isothyocyanate staining solution containing $4 \mathrm{X}$ saline-sodium cytrate, $0.1 \%$ Triton $\mathrm{X}$ 100 , and $2.5 \mu \mathrm{g} / \mathrm{ml}$ fluoresceined avidin (Vector, Burlingame, Calif.). Tubes were incubated for $30 \mathrm{~min}$ in the dark at room temperature. Cells were rinsed in PBS with $0.1 \%$ Triton X-100 and resuspended in $0.5 \mathrm{ml}$ PBS containing propidium iodide $(5 \mu \mathrm{g} / \mathrm{ml})$ and $70 \mu \mathrm{l}(1 \mathrm{mg} / \mathrm{ml})$ RNAse. Tubes were incubated in the dark on ice for $30 \mathrm{~min}$ prior to flow cytometric analysis.

\section{Results}

In Vitro Growth Suppression of Isogenic Mutants as a Result of Transient p53 Expression

To investigate the biological effect of wild-type $p 53$ in glioma cells that differ in their $p 53$ status, we infected isogenic cell lines U87-175.4 and U87-Lux.8 with Adp53 virus. Comparable transduction efficiency was observed in these cell lines after Ad- $\beta$ gal reporter virus infection (data not shown). After Ad-p53 infection, U87Lux.8 displayed morphology characteristically observed in senescence including flat, multinucleated cells. This behavior was similar to that which has been reported for U-87 MG cells infected with Ad-p53 (Gomez-Manzano et al., 1996). In contrast, a significant percentage of rounded, dead cells and cell membrane blebbing indicative of apoptosis was observed in U87-175.4 cultures after Ad-p53 infection (Fig. 1). Moreover, elevated levels of p53 in U87-175.4 cells led to a significant $(P<0.001)$ reduction in cell viability (Fig. 2). No features of apoptosis were evident in mock-infected U87-Lux.8 or U87175.4 cells nor in cells infected with $\operatorname{Ad} \Delta \mathrm{E} 1$, a replication-defective virus void of E1 and E3 genes. Although trypan blue exclusion results indicated similar degrees of cell viability in $\mathrm{Ad} \Delta \mathrm{E} 1$ infection control for both cell lines, some cytotoxicity was noted in $\operatorname{Ad} \Delta \mathrm{E} 1$-infected cultures compared with mock control. The apparent decrease in cell number can be attributed to growth suppression and not to cell death, as later determined by flow cytometry.

\section{Growth Suppression as a Consequence of Apoptosis}

Cell cycle analysis was performed using flow cytometry, and the sub-diploid (sub- $\mathrm{G}_{1}$ ) population was measured as an indication of apoptosis. A time-dependent increase in the sub- $\mathrm{G}_{1}$ population of Ad-p53-infected U87-175.4 cells was observed, as it escalated to $60.9 \%$ by $96 \mathrm{~h}$ postinfection. In contrast, no significant increase was evident in U87-Lux.8 cells infected with Ad-p53 (Table 1 and Fig. 3). These results correlate with cell viability measurements after Ad-p53 infection. Interestingly, a high percentage of cells in $G_{1}$ was detected in both cell lines before Ad-p53 infection. This can be attributed to slow cell growth rates previously recorded by Cell Titer 96AQ $\mathrm{Aeous}_{\text {us }}$ Non-Radioactive Cell Proliferation Assay (Promega, Madison, Wis.) (data not shown). Cell cycle analysis of U87-Lux.8 cells after Ad-p53 infection resembled that of infected U-87 MG (Gomez-Manzano et al., 1997). Both cell lines undergo a $G_{1}$ arrest postinfection; however, a small population of U87-Lux. 8 cells resumes cycling at $96 \mathrm{~h}$ (Table 1). In contrast, U87-175.4 cells infected with Ad-p53 exhibited no build-up in $G_{2} / M$ before undergoing apoptosis. The cell cycle distribution of U87-175.4 cells is unlike that of the control cell line U87-Lux.8. Cells infected with Ad $\Delta$ E1 virus experienced a background level of cytotoxicity often associated with adenoviral infections. However, flow cytometry and morphologic evidence portray healthy growing cells and indicate that minimal cell death present in control infections was not a result of apoptosis.

To examine whether acute levels of p53 have a generalized effect on other U87-175 transfectants, we performed TUNEL assays on cell lines U87-Lux.6, U87Lux.8, U87-175.4, and U87-175.13. Results shown in Table 2 demonstrated that a higher percentage of TUNEL-positive cells was detected in both isogenic mutant cell lines than in the control cell lines after Adp53 infection for different time intervals. Some toxicity was noted in U87-Lux.6 cells infected with $\mathrm{Ad} \Delta \mathrm{E} 1$. 

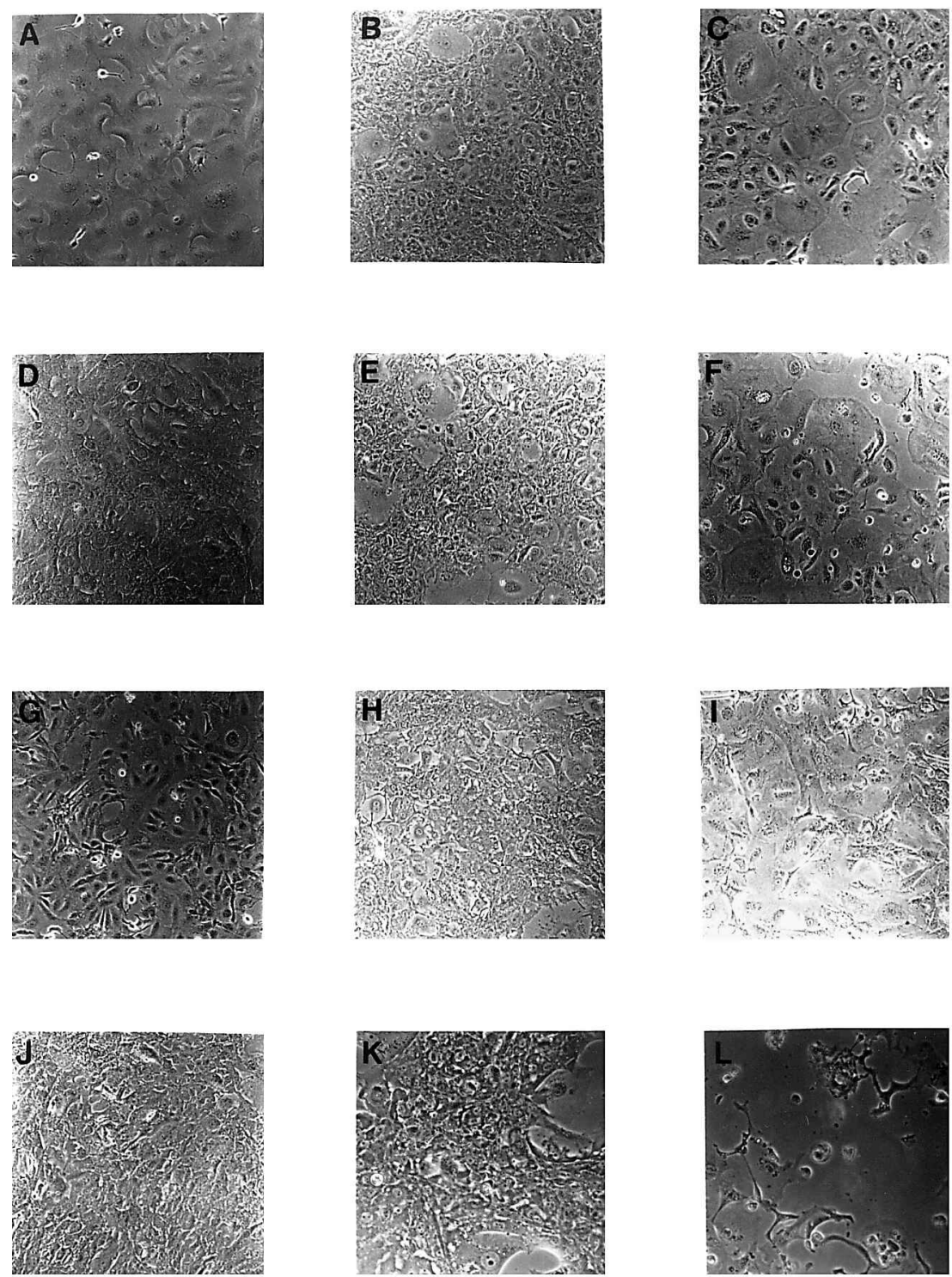

Fig. 1. Morphological analysis. Phase-contrast photomicrographs (original magnification $\times 100$ ) were taken of the U87-Lux.8 and U87-175.4 cells infected with either $\mathrm{Ad} \Delta \mathrm{E} 1$ or Ad-p53 for 48 and $96 \mathrm{~h}$ by using a diaphotomicroscope. A. Mock infection of U87-Lux.8 cells for $48 \mathrm{~h}$. B. Ad $\Delta$ E1 infection of U87-Lux.8 cells for 48 h. C. Ad-p53 infection of U87-Lux.8 for 48 h. D. Mock infection of U87-175.4 cells for 48 h. E. Ad $\Delta$ E1 infection of U87-175.4 cells for 48 h . F. Ad-p53 infection of U87-175.4 for 48 h. G. Mock infection of U87-Lux.8 cells for 96 h. H. Ad $\Delta$ E1 infection of U87-Lux.8 cells for $96 \mathrm{~h}$. I. Ad-p53 infection of U87-Lux.8 for $96 \mathrm{~h}$. J. Mock infection of U87-175.4 cells for $96 \mathrm{~h}$. K. Ad $\Delta$ E1 infection of U87-175.4 cells for $96 \mathrm{~h}$. L. Ad-p53 infection of U87-175.4 for $96 \mathrm{~h}$. Note there are fewer cells in panel $\mathrm{L}$ and cells with blebbed membranes, which is indicative of an apoptotic event occurring in these cells.

Taken together, these results suggested that the introduction of mutant $p 53(175 \mathrm{H})$ into a cell line containing a wild type $p 53$ resulted in a generalized apoptotic-sensitive phenotype in response to Ad-p53 infection. It is noteworthy that both U87-175.4 and U87-175.13 cell lines exhibited a high rate of spontaneous apoptosis of $8.6 \%$ and $7.1 \%$, respectively, as detected in $72 \mathrm{~h}$ post-Ad-p53 infection.

To test the ability of other $p 53$ mutants in sensitizing U-87 MG to Ad-p53-induced apoptosis, 2 additional isogenic p53-mutant cell lines overexpressing a mutant p53 $(248 \mathrm{~W}$ or $273 \mathrm{H})$ were generated. Twenty different clones from each mutant construct were isolated and analyzed for $p 53$ expression by Western blot analysis (data not shown). Based on Western blot analysis, 2 clonal cell lines expressing highest levels of p53, U87248-1, and U87-273-D, as well as a cell line U87C expressing an empty vector, were infected with $100 \mathrm{MOI}$ of Ad-p53. DNA content and cell cycle profiles were determined by propidium iodide staining and fluorescence-activated cell sorting analysis. Both cell lines exhibited an increase in the percentage of sub- $G_{1}$ population after Ad-p53 infection (Table 3). These results suggest that at least 3 different $p 53$ mutants can sensitize wildtype $p 53$-expressing cells to Ad-p53-induced apoptosis to varying degrees. 


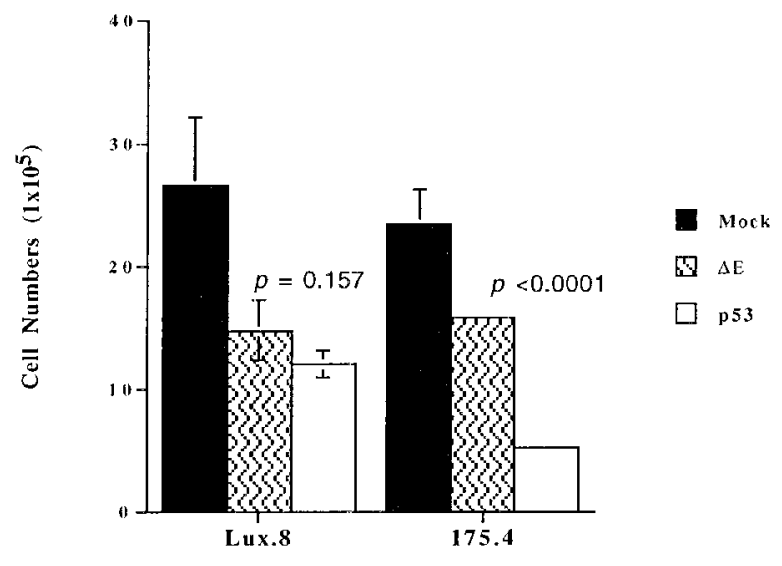

Fig. 2. Viability assay: Effects of exogenous p53 on the growth of U87-Lux. 8 and U87-175.4 cells. The cells were plated at low density and were infected with $\mathrm{Ad} \Delta \mathrm{E} 1$ or $\mathrm{Ad}-\mathrm{p} 53$ for $96 \mathrm{~h}$ before being assessed for their viability by using trypan blue exclusion dye. The number of viable cells displayed includes the mean \pm SD of triplicate experiments, and $P$ values were determined by $t$-test analyses between $\mathrm{Ad} \Delta \mathrm{E} 1$ and $\mathrm{Ad}$-p53 data. SDs of U87-175.4 experiments were too small to appear in the graph. The assay was repeated a minimum of 3 times.

\section{Expression of p53 Target Genes After Ad-p53 Infection}

Immunoblots for $p 53$ expression revealed up to a 4-fold increase in protein levels in both U87-175.4 and U87Lux.8 infected with Ad-p53 (Fig. 4A). U87-175.4 exhibited higher endogenous levels of $p 53$ than did U87Lux.8, presumably due to the expression of mutant $p 53$ $(175 \mathrm{H})$. Western blot analyses were performed to examine differential expression of known $p 53$ target genes in response to Ad-p53 infection.

Overexpression of $M D M 2$, a negative regulator of $p 53$, has been shown to inactivate wild-type $p 53$ and prevent apoptosis (Chen et al., 1996). We sought to determine if irregular expression of MDM2 was responsible for resistance to $p 53$-mediated apoptosis in our system. Western blot analysis indicated that similar levels of MDM2 were detected in both U87-Lux.8 and U87-175.4 up to $96 \mathrm{~h}$ after infection, whereas undetectable levels of MDM2 were noted in the mock and $\operatorname{Ad} \Delta$ E1-infected control cells (Fig. 4B). These levels were consistent with those recorded after overexpression of $p 53$ through DNA damage or apoptotic insult (An et al., 1998). Although allelic exclusion or mutations in MDM2 have been associated with abnormalities in $p 53$ in numerous cell lines (Cheng et al., 1995), it appears that differential MDM2 expression was not responsible for the differences in apoptotic response demonstrated by U87-Lux.8 and U87-175.4.

Overexpression of BCL2 has been shown to inhibit p53-mediated apoptosis after various apoptotic stimuli. We examined whether there were alterations in BCL2 protein levels involved in Ad-p53-induced apoptosis in U87-175.4. Endogenously, U87-Lux.8 and U87-175.4 express comparable levels of BCL2 as shown in mockand $\mathrm{Ad} \triangle \mathrm{E} 1$-infected samples (Fig. 5). However, BCL2 expression in U87-Lux.8 cells decreased at $48 \mathrm{~h}$ post-Adp53 infection and were sustained at such a level until 96 h (Fig. 5). In contrast, after Ad-p53 infection, BCL2 levels in U87-175.4 cells appeared to increase modestly at $48 \mathrm{~h}$ and $72 \mathrm{~h}$ with respect to the $24 \mathrm{~h}$ level, yet were not significantly greater than mock or $\mathrm{Ad} \Delta \mathrm{E} 1$ samples. These findings, however, did not fully account for cell viability or TUNEL results and suggested that the involvement of other BCL2 family members may contribute to inhibiting apoptosis in the wild-type $p 53$ glioma (McDonnell et al., 1996). Therefore, Bcl- $X_{L}$ protein expression was examined under the same conditions. No differences in expression were detected between uninfected and Adp53-infected cells (data not shown). Similarly, there was no indication that differences in BAX protein levels measured after Ad-p53 infection were responsible for the observed differences in apoptotic response displayed by U87-Lux.8 and U87-175.4. The role of other BCL2 family members in this model system remains to be determined and is currently under investigation.

$\mathrm{p} 21^{\mathrm{WAF} 1 / \mathrm{CIP} 1}$ is a key cell cycle regulator that mediates growth arrest by inhibiting the action of $\mathrm{G}_{1}$ cyclin-dependent kinases (Waga et al., 1994). As a downstream target of $p 53$, $\mathrm{p} 21^{\mathrm{WAF} 1 / \mathrm{CIP} 1}$ levels can be induced after Ad-p53 infection in glioma cell lines regardless of their p53 status (GomezManzano et al., 1997). We sought to determine whether Ad-p53 infection induces $p 21^{\text {WAF1/CIP1 }}$ expression and promotes cell cycle arrest in U87-Lux.8 and U87-175.4 cells. Western blot analysis showed higher levels of p21 $1^{\text {WAF1/CIP1 }}$ expression in U87-Lux.8 cells than in U87175.4 cells during $24-72 \mathrm{~h}$ postinfection (Fig. 5). Protein levels appeared to decrease in both cell lines at $96 \mathrm{~h}$ postinfection. Decreases in $p 21^{\text {WAFI/CIP1 }}$ expression correlated well with the concomitant reduction of $G_{1}$ cell population observed in cell cycle analysis (Fig. 5 and Table 1).

Table 1. Cell cycle analysis of U87-Lux.8 and U87-175.4 cells treated for $48 \mathrm{~h}$ and $96 \mathrm{~h}$ with $\mathrm{Ad} \Delta \mathrm{E} 1$ or Ad-p53

U87-Lux.8

\begin{tabular}{|c|c|c|c|c|c|c|c|c|}
\hline \multirow[b]{2}{*}{ Cell phase } & \multicolumn{2}{|c|}{$48 \mathrm{~h}$} & \multicolumn{2}{|c|}{$96 \mathrm{~h}$} & \multicolumn{2}{|c|}{$48 \mathrm{~h}$} & \multicolumn{2}{|c|}{$96 \mathrm{~h}$} \\
\hline & $\Delta \mathrm{E} 1$ & p53 & $\Delta \mathrm{E} 1$ & p53 & $\Delta \mathrm{E} 1$ & p53 & $\Delta \mathrm{E} 1$ & p53 \\
\hline$\overline{G_{1}(\% \text { cells })}$ & 73.9 & 82.9 & 84.1 & 76.0 & 81.4 & 81.7 & 83.1 & 66.0 \\
\hline S (\% cells) & 10.8 & 7.0 & 11.2 & 17.9 & 11.5 & 12.2 & 11.2 & 25.2 \\
\hline $\mathrm{G}_{2} / \mathrm{M}$ (\% cells) & 10.3 & 10.0 & 4.7 & 6.1 & 7.0 & 6.1 & 5.7 & 8.8 \\
\hline Sub-G ${ }_{1}$ ( $\%$ cells) & 1.2 & 1.7 & 8.4 & 5.0 & 2.0 & 19.9 & 2.5 & 60.9 \\
\hline
\end{tabular}

Cells $\left(1-2 \times 10^{6}\right)$ were infected with $100 \mathrm{MOI}$ of AdAE1 or Ad-p53 for $48 \mathrm{~h}$ or $96 \mathrm{~h}$. After infection, total cells, including the floating cells, were harvested and subjected to flow cytometric analysis. 
A U87-Lux.8
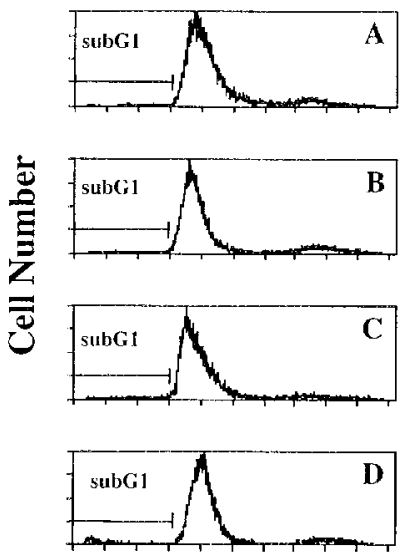

DNA Content
U87-175.4
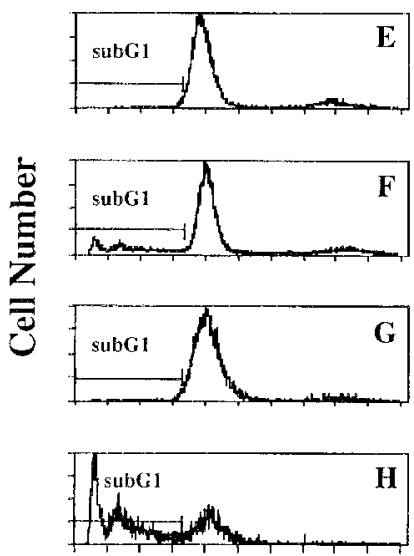

DNA Content

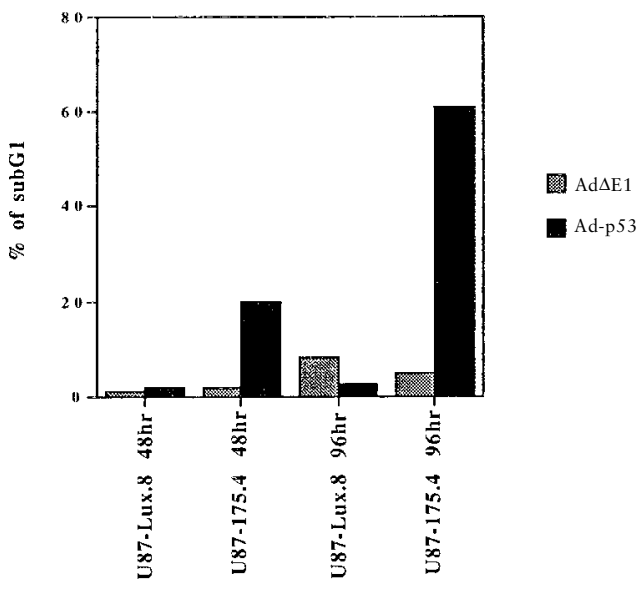

Fig. 3. Cell cycle analysis. U87-Lux.8 and U87-175.4 cells were infected with Ad $\Delta \mathrm{E} 1$ or Ad-p53 virus for $48 \mathrm{~h}$ and $96 \mathrm{~h}$. Cells were then harvested for cell cycle analysis. A. U87-Lux.8 cells infected with Ad $\Delta$ E1 (A for $48 \mathrm{~h}$ and C for $96 \mathrm{~h}$ ) or with Ad-p53 (left panel; B for $48 \mathrm{~h}$ and $D$ for 96 h); and U87-175.4 cells infected with Ad $\Delta E 1$ (right panel; E for $48 \mathrm{~h}$ and $\mathrm{G}$ for $96 \mathrm{~h}$ ) or with Ad-p53 ( $\mathrm{F}$ for $48 \mathrm{~h}$ and $\mathrm{H}$ for $96 \mathrm{~h}$ ). The sub- $G_{1}$ population of cells is as indicated. $B$. Percentage of sub- $G_{1}$ cell population. The sub- $G_{1}$ percentage represents the cellular fraction containing less than 2n DNA indicative of apoptosis.

\section{PARP Cleavage Was Evident in U87-175.4 Cells upon p53-Induced Apoptosis}

Involvement of caspases in cell death is a hallmark for apoptosis. We examined whether overexpression of $p 53$ in both U87-Lux. 8 and U87-175.4 cells would lead to differential expression of a central caspase, CPP32 (caspase-3), and subsequently apoptosis in U87-175.4 cells. Western blot analysis was used to measure the levels of the proform of CPP32 as an indicator of caspase activation. In the U87-Lux. 8 cell line, CPP32 levels increased at 48 h post Ad-p53 infection compared with controls (Fig. $6 \mathrm{~A})$. The significance of the accumulation of CPP32 proform is unclear. However, U87-Lux.8 cells do not undergo apoptosis when assayed longer than $96 \mathrm{~h}$ post-Ad-p53 infection (data not shown). Interestingly, no changes in the proform of CPP32 were detected in Ad-p53-infected U87-175.4 cells (Fig. 6A).

Characteristic with the onset of apoptosis is the cleavage of enzymes that are responsible for DNA fragmentation. PARP functions as a DNA repair enzyme and is cleaved by caspases during apoptosis. PARP is a downstream target of multiple caspases, including caspase-2,
CPP32, caspase-7, and caspase-9 (King et al., 1998). We examined whether the apoptotic event detected in U87175.4 cells involved PARP cleavage. Western blot analysis for the identification of PARP cleavage was performed using C2-10 anti-PARP antibody. The $85-\mathrm{kDa}$ cleaved product can be detected as early as $48 \mathrm{~h}$ after Ad-p53 infection and is visible for up to $96 \mathrm{~h}$ after infection (Fig. 6B). However, in the mock-infected and $\operatorname{Ad} \Delta \mathrm{E} 1$-infected controls, a cleaved product of PARP was also detected, yet to a lesser degree. A similar analysis was performed for U87-Lux.8 cells. Western blot analysis indicates that no cleavage product corresponding to the molecular mass of $85 \mathrm{kDa}$ was evident in U87-Lux.8 cells infected with Ad-p53 virus (Fig. 6B). Furthermore, in contrast to what was observed in U87-175.4 cells, no basal level of the $85-\mathrm{kDa}$ protein was detected in the mock- and Ad $\Delta$ E1-infected controls for U87-Lux.8 cells.

\section{Enzymatic Activity of Caspases After Ad-p53 Infection}

To further confirm the apoptotic induction by $\mathrm{p} 53$ in U87-175.4, we performed a more sensitive assay by measuring the activity of several caspases. Both U87-Lux.8

Table 2. TUNEL analysis of U-87 MG derivatives after infection with $\mathrm{Ad}-\mathrm{p} 53, \mathrm{Ad} \Delta \mathrm{E} 1$, or culture medium (mock)

\begin{tabular}{|c|c|c|c|c|c|c|c|c|}
\hline \multirow[b]{2}{*}{ Vector } & \multicolumn{2}{|c|}{ U87-Lux.8 } & \multicolumn{2}{|c|}{ U87-175.4 } & \multicolumn{2}{|c|}{ U87-Lux.6 } & \multicolumn{2}{|c|}{ U87-175.13 } \\
\hline & $24 \mathrm{~h}$ & $72 \mathrm{~h}$ & $24 \mathrm{~h}$ & $72 \mathrm{~h}$ & $24 \mathrm{~h}$ & $72 \mathrm{~h}$ & $24 \mathrm{~h}$ & $72 \mathrm{~h}$ \\
\hline Mock & 0.7 & 0.8 & 6.2 & 8.6 & 3.5 & 3.8 & 2.4 & 7.1 \\
\hline $\operatorname{Ad} \Delta \mathrm{E} 1$ & 0.8 & 3.7 & 5.0 & 6.0 & 5.3 & 26.3 & 2.6 & 6.3 \\
\hline Ad-p53 & 0.8 & 4.6 & 8.2 & 39.4 & 7.9 & 23.9 & 3.3 & 29.3 \\
\hline
\end{tabular}

Cells $\left(2 \times 10^{6}\right)$ were infected with $100 \mathrm{MOI}$ of $\mathrm{Ad} \Delta \mathrm{E} 1$ or Ad-p53 for $24 \mathrm{~h}$ or $72 \mathrm{~h}$. Mock infection with medium was used as a control. After infection, cells were harvested and $1 \times 10^{6}$ cells were subjected to TUNEL analysis. The numbers shown are the percentage of TUNEL-positive cells indicating apoptosis. 
Table 3. Cell cycle analysis of U87-248-1 and U87-273-D cells after treatment with Ad $\Delta \mathrm{E} 1$ or Ad-p53 for $48 \mathrm{~h}$ or $96 \mathrm{~h}$

\begin{tabular}{|c|c|c|c|c|c|c|c|c|c|c|c|c|}
\hline \multirow[b]{3}{*}{ Cell phase } & \multicolumn{4}{|c|}{ U87-248-1 } & \multicolumn{4}{|c|}{ U87-273-D } & \multicolumn{4}{|c|}{ U87 control } \\
\hline & \multicolumn{2}{|c|}{$48 \mathrm{~h}$} & \multicolumn{2}{|c|}{$96 \mathrm{~h}$} & \multicolumn{2}{|c|}{$48 \mathrm{~h}$} & \multicolumn{2}{|c|}{$96 \mathrm{~h}$} & \multicolumn{2}{|c|}{$48 \mathrm{~h}$} & \multicolumn{2}{|c|}{$96 \mathrm{~h}$} \\
\hline & $\Delta \mathrm{E} 1$ & p53 & $\Delta \mathrm{E} 1$ & p53 & $\Delta \mathrm{E} 1$ & p53 & $\Delta \mathrm{E} 1$ & p53 & $\Delta \mathrm{E} 1$ & p53 & $\Delta \mathrm{E} 1$ & p53 \\
\hline$\%$ cells $\mathrm{G}_{1}$ & 65.6 & 81.1 & 72.6 & 81.4 & 59.8 & 81.9 & 70.7 & 80.6 & 68.8 & 80.9 & 73.3 & 75.1 \\
\hline$\%$ cells S & 17.6 & 6.5 & 8.7 & 8.9 & 18.5 & 7.0 & 8.5 & 8.7 & 14.3 & 6.3 & 6.9 & 8.3 \\
\hline$\%$ cells $\mathrm{G}_{2} / \mathrm{M}$ & 16.8 & 14.5 & 18.7 & 9.8 & 21.7 & 11.1 & 20.7 & 10.7 & 16.9 & 12.8 & 19.7 & 16.6 \\
\hline$\%$ cells Sub-G1 & 3.8 & 4.8 & 4.8 & 15.4 & 2.0 & 1.9 & 4.8 & 13.3 & 2.8 & 1.0 & 3.3 & 3.7 \\
\hline
\end{tabular}

Cells $\left(2 \times 10^{6}\right)$ were infected with $100 \mathrm{MOI}$ of $\mathrm{Ad} \Delta \mathrm{E} 1$ or Ad-p53 for $48 \mathrm{~h}$ or $96 \mathrm{~h}$. After infection, total cells, including the floating cells, were harvested and subjected to flow cytometric analysis.

and U87-175.4 cell lines were mock-infected, $\operatorname{Ad} \Delta \mathrm{E} 1$ infected, or Ad-p53 infected for $96 \mathrm{~h}$, and cell extracts were assayed for caspase-1, -2 , and -3 activity using a commercial kit (R\&D Systems, Minneapolis, Minn.). There was no induction of caspase- 1 activity in both cell lines after Ad-p53 infection. However, U87-175.4 cells exhibited approximately a 2 -fold induction of caspase- 2 and -3 enzymatic activity after Ad-p53 infection compared with $\operatorname{Ad} \Delta \mathrm{E} 1$-infected extracts (Fig. 7). A minimal induction of both caspase- 2 and caspase- 3 activities was observed in U87-Lux.8 cells after Ad-p53 infection. Furthermore, induction of caspase- 2 and caspase- 3 enzymatic activity in U87-175.4 correlated with TUNEL and cell viability results.

\section{Discussion}

Current ideology aims to use gene therapy (Fujiwara et al., 1996) or synthetic peptides (Hupp et al., 1995) to restore wild-type $p 53$ function in cells harboring a mutant $\mathrm{p} 53$ protein or those that have defective p53 pathways. Although some success with this approach has been achieved, cell types remain that are nonresponsive to these forms of therapy. Despite the ongoing gene therapy trial using Ad-p53 for glioma patients, the underlying mechanism of differential response to apoptotic induction after Ad-p53 infection is unclear. In this study, we sought to investigate the importance of $p 53$ status in response to Ad-p53-induced apoptosis. We hypothesized that the introduction of a mutant $p 53$ into a wild-type p53-containing cell line would sensitize the cells to Adp53-induced apoptosis. Our results demonstrated that p53 status in glioma cells is integral to determining cellular fate after Ad-p53 insult.

Isogenic mutant cell lines of U87-Lux.8 and U87175.4 have been used to demonstrate that the overexpression of a mutant $p 53$ in a wild-type p53-expressing cell line alters its radiosensitive phenotype (Yount et al., 1996). Using these cell lines, we demonstrated that the reintroduction of a functional wild-type $p 53$ via adenoviral-mediated gene transfer into U87-175.4 cells results in an apoptotic-sensitive phenotype similar to cell lines with endongenous $p 53$ mutations. Interestingly, other p53 mutants such as $248 \mathrm{~W}$ and $273 \mathrm{H}$ also exert similar effects as $175 \mathrm{H}$, albeit less effectively. Several studies support the active role of multiple mutant $p 53$ genes in transcription and protein-protein interactions
(Friedlander et al., 1996; Selivanova et al., 1997). Evidence by Zhang et al. (1993) indicates that both 273 and 175 mutants can retain their DNA binding and transcriptional activity. Alternatively, Hachiya et al. (1994) have demonstrated that both the 175 and 248 mutants, but not 273 , can suppress wild-type $p 53$ transcriptional activity when co-expressed in cells. Because the extent of apoptotic induction elicited by these p53 mutants varied, the effect on apoptotic response by these mutants may reflect their differential binding activity to the $p 53$-responsive element.

A

U87-Lux.8

U87-175.4

Ad-p53

Ad-p53
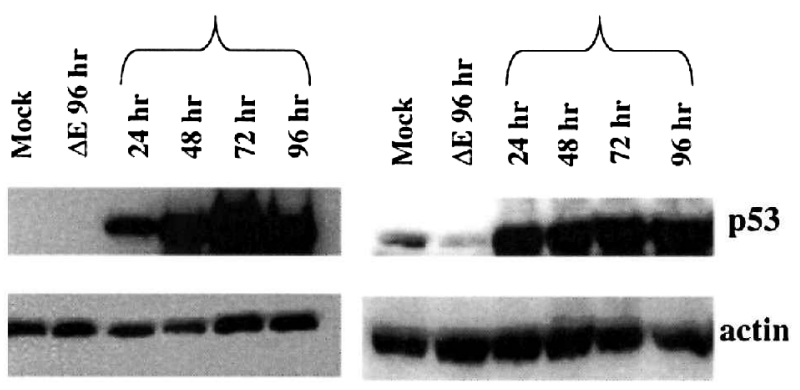

B
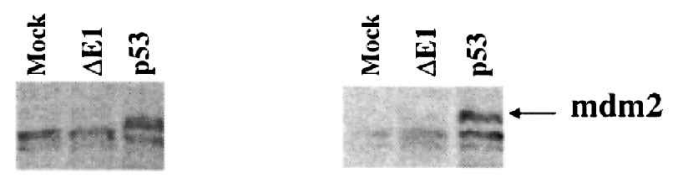

Fig. 4. A. Time-dependent expression of p53 protein in U87-Lux.8 and U87-175.4 cells after Ad-p53 infection. Western blot analysis was performed on the cell lysates by using an anti-p53 antibody (DO-1). Expression of p53 protein increased in a time-dependent fashion. Mutant p53 protein was also detected only in the mock and $\mathrm{Ad} \Delta \mathrm{E} 1$ controls of U87-175.4 cells compared with the same controls of U87-Lux.8 cells. B. Expression of MDM2 protein in U87-Lux.8 and U87-175.4 cells after Ad-p53 infection. Western blot analysis was performed on cell lysates extracted from cells $96 \mathrm{~h}$ after Ad-p53 infection. In both cell lines, MDM2 expression was induced only in Ad-p53 infected cells compared with controls, indicating that the exogenous $\mathrm{p} 53$ retained its normal function. 


\section{U87-Lux.8}
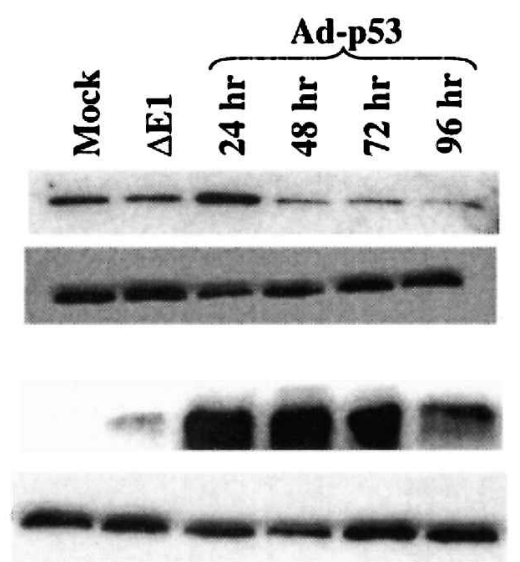

U87-175.4

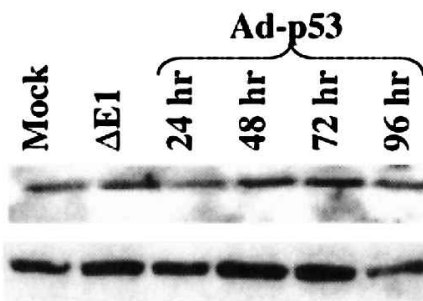

Bcl-2

Actin

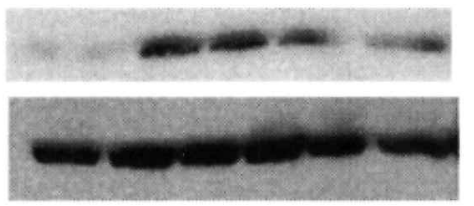

p21

Actin

Fig. 5. Expression of p53-responsive genes in U87-Lux.8 and U87-175.4 cells after Ad-p53 infection. Western blot analyses were performed to examine $B C L 2$ and $p 21^{\text {WAF1/CIP1 }}$ expression at indicated time intervals in response to Ad-p53 infection in both cell lines.

The most outstanding difference between the two cell lines examined in response to Ad-p53 infection was the degree of apoptosis exhibited by U87-175.4 cells. The solitary difference between U87-Lux.8 and U87-175.4 cells is the presence of mutant $p 53$ in U87-175.4 cells. Although expression of mutant $p 53$ in U87-175.4 cells altered its phenotype in response to Ad-p53, its degree of sensitivity to p53-mediated apoptosis is not identical to that of the natural p53 mutant cell such as U-251 MG. One possible explanation for the observed difference lies in the frequency of multiple mutations in glioblastoma genesis. Alterations in genes such as $R B, M M A C / P T E N$, and $p 16 / p 14^{\text {arf }}$ result in a multitude of destabilized pathways and may contribute to the sensitivity to Ad-p53. In addition, the formation of wild-type $p 53$ and mutant $p 53$ heterodimers may affect transcriptional regulation of key apoptotic genes and account for the phenotype of the isogenic cell lines. These heterotetramers may preferentially activate genes or interfere with regulators that induce apoptosis.

We determined that the expression of $p 53$ was elevated in both U87-Lux.8 and U87-175.4 cells after Adp53 infection. Therefore, the apoptosis observed in U87175.4 cells was not a consequence of differential $p 53$ expression, rather the difference in apoptotic response

A

U87-Lux.8

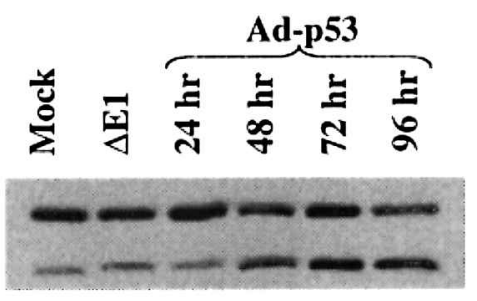

B

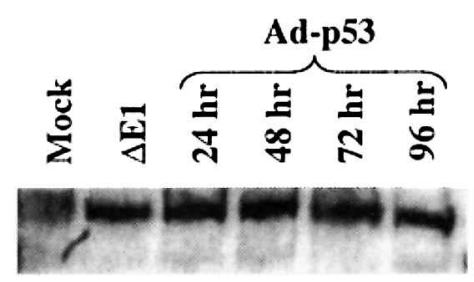

U87-175.4

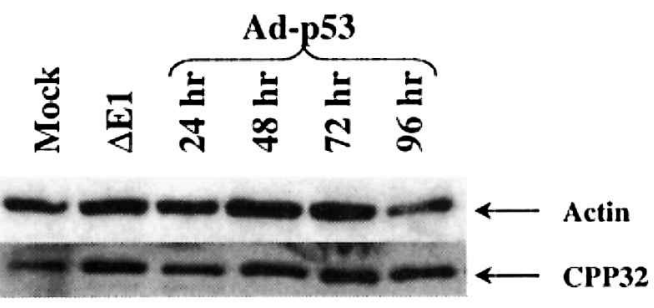

U87-175.4

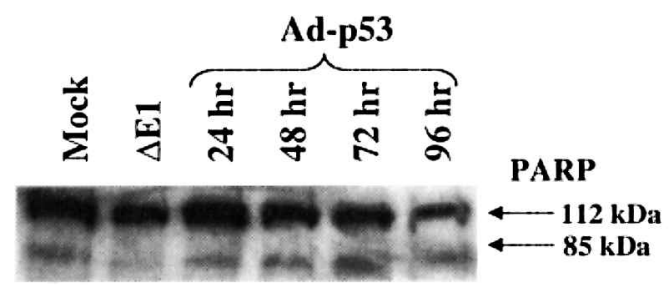

Fig. 6. Western blot analyses of the activation of caspase-3 (СPP32) on U87-Lux.8 and U87-175.4 cells after p53 transfer. A. Expression of CPP32 protein was detected with a polyclonal antibody. In the U87-Lux.8 cell line, CPP32 levels increased at $48 \mathrm{~h}$ post-Ad-p53 infection as compared with controls, whereas the levels of CPP32 in U87-175.4 remained constant. B. Cleavage of PARP was detected in U87-175.4 cells. 
Caspase 1

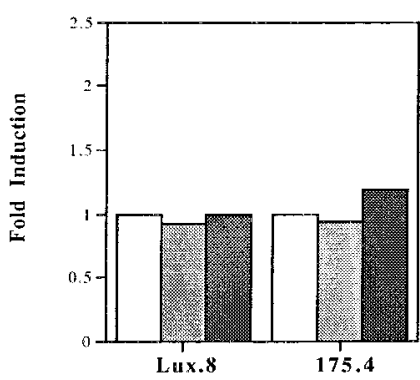

Caspase 2

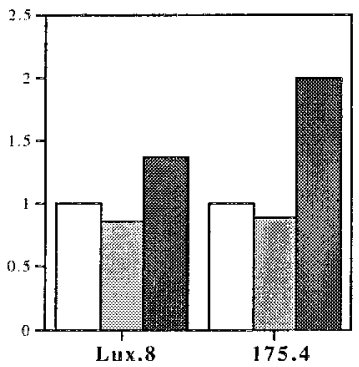

Caspase 3

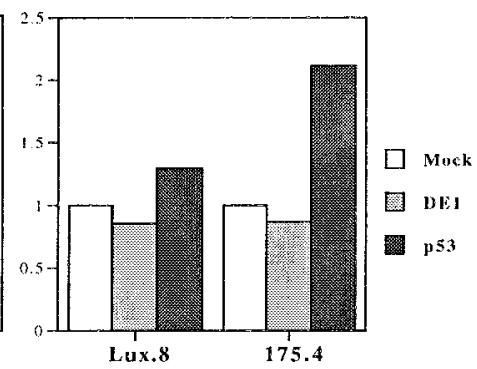

Fig. 7. Enzymatic activity of caspases. Both U87-Lux.8 and U87-175.4 cell lines were mock Ad $\Delta$ E1- or Ad-p53-infected for 96 h. Cellular extracts were assayed for enzymatic activity of caspase-1, caspase-2, and caspase-3 by using commercial kits. Fold induction was calculated by dividing the activity of each experiment with that of the mock control. Experiments were repeated 3 times with similar results.

may reflect differences in the transcription of $p 53$ target genes. With regard to this possibility, both cell lines expressed elevated levels of $221^{\text {WAF1/CIP1 }}$ after Ad-p53 infection, suggesting that the $\mathrm{p} 53 / \mathrm{p} 21^{\mathrm{WAF} 1 / \mathrm{CIP} 1}$ pathway was not compromised in either cell line. Additionally, the levels of MDM2, a negative regulator of $\mathrm{p} 53$ function, were unaltered in these 2 cell lines after Ad-p53 infection. The potential involvement of both BCL2 and BAX was also examined. After Ad-p53 infection, BCL2 levels appeared to decrease in U87-Lux.8 cells over time, in contrast with those that remained unchanged in U87175.4-infected cells. No noticeable changes of $B A X$ expression in either U87-Lux.8 or U87-175.4 were evident. Results of BCL2 and BAX expression in the isogenic mutant cell lines contradict the results from cell viability and TUNEL assays showing that U87-Lux.8 cells are resistant to $p 53$-induced apoptosis.

One of the most important downstream mediators of the caspase cascade is CPP32. Differences in the endogenous levels of CPP32 were evident in the 2 cell lines studied whereby U87-175.4 cells display higher levels of the pro-CPP32 protein than did U87-Lux.8 cells. Interestingly, levels of the proform of the enzyme increased after Ad-p53 infection in U87-Lux.8 but not in U87-175.4 cells. It is likely that this increase is a result of the inability of cellular machinery to activate CPP32 and contributes to its apoptotic insensitive phenotype. In contrast, the levels of pro-CPP32 in Ad-p53-infected U87175.4 cells remain constant and may be due to continual processing of the procaspase. A more sensitive enzymatic assay for caspase activity revealed that several caspases, including caspase- 2 and caspase-3, were activated after Ad-p53 infection on U87-175.4 cells. These results point toward the involvement of complex proteolytic systems whereby a combination of proteases, cofactors, inhibitors, feedback loops, and thresholds act in concert to execute an apoptotic signal (Thornberry and Lazebnik, 1998). Finally, the DNA repair enzyme PARP was cleaved in U87-175.4 cells but not in U87-Lux.8 cells after Ad-p53 infection. These data confirm that PARP cleavage is indeed an active part of p53-mediated apoptosis in glioma and includes the activation of multiple caspases. In this study we examined the effect of Ad-p53 on the expression of only a few key target genes. It is likely that other genes may contribute to the sensitization of U87-175.4 cells to p53-induced apoptosis. Efforts to employ techniques such as the DNA array, for the profiling of multiple gene expression in response to $\mathrm{Ad}-\mathrm{p} 53$, are under way.

Taken together, our results demonstrate the importance of $p 53$ status in governing cellular fate after Adp53 treatment. The ability to alter an apoptotic-resistant phenotype indicates that intrinsic apoptotic pathways are functional in U-87 MG cells and can be reinitiated upon the change in 753 status. Understanding p53 pathways and the mediators of the apoptotic response in glioma will significantly facilitate the design of novel antitumor strategies. Gaining insight into the intricate mechanisms of resistance in glioma will enable us to pinpoint the genes or pathways to target for radiation or gene therapy.

\section{Acknowledgments}

We thank Drs. Mark A. Israel and Daphne A. HaasKogan for providing the U87-Lux and U87-175 cell lines and Dr. Wei Zhang for the vectors expressing p53mutant $248 \mathrm{~W}$ and $273 \mathrm{H}$. We also thank Mary Wang for the preparation of adenoviral vectors and Vikie Williams for editorial assistance.

\section{References}

An, W.G., Chuman, Y., Fojo, T., and Blagosklonny, M.V. (1998) Inhibitors of transcription, proteasome inhibitors, and DNA feedback of p53 degradation. Exp. Cell Res. 244, 54-60.

Carmeliet, P., Dor, Y., Herbert, J.M., Fukumura, D., Brusselmans, K., Dewerchin, M., Neeman, M., Bono, F., Abramovitch, R., Maxwell, P., Koch,
C.J., Ratcliffe, P., Moons, L., Jain, R.K., Collen, D., and Keshet, E. (1998) Role of HIF-1 $\alpha$ in hypoxia-mediated apoptosis, cell proliferation and tumour angiogenesis. Nature 394, 485-490.

Chen, J., Wu, X., Lin, J., and Levine, A.J. (1996) mdm-2 inhibits the G1 arrest and apoptosis functions of the p53 tumor suppressor protein. Mol. Cell. 
Biol. 16, 2445-2452.

Cheng, Y.T., Li, Y.L., Wu, J.D., Long, S.B., Tzai, T.S., Tzeng, C.C., and Lai, M.D. (1995) Overexpression of MDM-2 mRNA and mutation of the p53 tumor suppressor gene in bladder carcinoma cell lines. Mol. Carcinog. 13, 173-181.

Dameron, K.M., Volpert, O.V., Tainsky, M.A., and Bouck, N. (1994) Control of angiogenesis in fibroblasts by $\mathrm{p} 53$ regulation of thrombospondin-1. Science 265, 1582-1584.

el-Deiry, W.S., Tokino, T., Velculescu, V.E., Levy, D.B., Parsons, R., Trent, J.M., Lin, D., Mercer, W.E., Kinzler, K.W., and Vogelstein, B. (1993) WAF1, a potential mediator of p53 tumor suppression. Cell 75, 817-825.

el-Deiry, W.S., Harper, J.W., O'Connor, P.M., Velculescu, V.E., Canman, C.E., Jackman, J., Pietenpol, J.A., Burrell, M., Hill, D.E., and Wang, Y. (1994) WAF1/CIP1 is induced in p53-mediated $\mathrm{G} 1$ arrest and apoptosis. Cancer Res. 54, 1169-1174.

Friedlander, P., Haupt, Y., Prives, C., and Oren, M. (1996) A mutant p53 that discriminates between p53-responsive genes cannot induce apoptosis. Mol. Cell. Biol. 16, 4961-4971.

Fujiwara, T., Kagawa, S., Ogawa, N., Yasuda, T., Tanaka, N., Orita, K., Cai, D.W., Zhang, W.W., and Roth, J.A. (1996) Recombinant virus-mediated transfer of the wild-type p53 gene is a potent therapeutic strategy for human cancer. Hum. Cell. 9, 25-30.

Fults, D., Brockmeyer, D., Tullous, M.W., Pedone, C.A., and Cawthon, R.M. (1992) p53 mutation and loss of heterozygosity on chromosomes 17 and 10 during human astrocytoma progression. Cancer Res. 52, 674-679.

Gomez-Manzano, C., Fueyo, J., Kyritsis, A.P., Steck, P.A., Roth, J.A., McDonnell, T.J., Steck, K.D., Levin, V.A., and Yung, W.K. (1996) Adenovirusmediated transfer of the $\mathrm{p} 53$ gene produces rapid and generalized death of human glioma cells via apoptosis. Cancer Res. 56, 694-699.

Gomez-Manzano, C., Fueyo, J., Kyritsis, A.P., McDonnell, T.J., Steck, P.A., Levin, V.A., and Yung, W.K. (1997) Characterization of p53 and p21 functional interactions in glioma cells en route to apoptosis. J. Natl. Cancer Inst. 89, 1036-1044.

Hachiya, M., Chumakov, A., Miller, C.W., Akashi, M., Said, J., and Koeffler, H.P. (1994) Mutant p53 proteins behave in a dominant, negative fashion in vivo. Anticancer Res 14, 1853-1859.

He, J., Reifenberger, G., Liu, L., Collins, V.P., and James, C.D. (1994) Analysis of glioma cell lines for amplification and overexpression of MDM2. Genes Chromosomes Cancer 11, 91-96.

Hollander, M.C., Alamo, I., Jackman, J., Wang, M.G., McBride, O.W., and Fornace, A.J., Jr. (1993) Analysis of the mammalian gadd45 gene and its response to DNA damage. J. Biol. Chem. 268, 24385-24393.

Hupp, T.R., Sparks, A., and Lane, D.P. (1995) Small peptides activate the latent sequence-specific DNA binding function of p53. Cell 83, 237-245.

Hsiao, M., Low, J., Dorn, E., Ku, D., Pattengale, P., Yeargin, J., and Haas, M. (1994) Gain-of-function mutations of the p53 gene induce lymphohematopoietic metastatic potential and tissue invasiveness. Am. J. Pathol.
$145,702-714$

King, D., Pringle, J.H., Hutchinson, M., and Cohen, G.M. (1998) Processing/activation of caspases, -3 and -7 and -8 but not caspase- 2 , in the induction of apoptosis in B-chronic lymphocytic leukemia cells. Leukemia 12, 1553-1560.

Liu, T.J., el-Naggar, A.K., McDonnell, T.J., Steck, K.D., Wang, M., Taylor, D.L., and Clayman, G.L. (1995) Apoptosis induction mediated by wild-type p53 adenoviral gene transfer in squamous cell carcinoma of the head and neck. Cancer Res. 55, 3117-3122.

Liu, T.J., Wang, M., Breau, R.L., Henderson, Y., El-Naggar, A.K., Steck, K.D., Sicard, M.W., and Clayman, G.L. (1999) Apoptosis induction by E2F-1 via adenoviral-mediated gene transfer results in growth suppression of head and neck squamous cell carcinoma cell lines. Cancer Gene Ther. 6, 163-171.

McDonnell, T.J., Beham, A., Sarkiss, M., Andersen, M.M., and Lo, P. (1996) Importance of the Bcl-2 family in cell death regulation. Experientia 52, 1008-1017.

Miyashita, T., and Reed, J.C. (1995) Tumor suppressor p53 is a direct transcriptional activator of the human bax gene. Cell 80, 293-299.

Nielsen, L.L., and Maneval, D.C. (1998) P53 tumor suppressor gene therapy for cancer. Cancer Gene Ther. 5, 52-63.

Owen-Schaub, L.B., Zhang, W., Cusack, J.C., Angelo, L.S., Santee, S.M., Fujiwara, T., Roth, J.A., Deisseroth, A.B., Zhang, W.W., and Kruzel, E. (1995) Wild-type human p53 and a temperature-sensitive mutant induce Fas/APO-1 expression. Mol. Cell. Biol. 15, 3032-3040.

Selivanova, G., lotsova, V., Okan, I., Fritsche, M., Strom, M., Groner, B., Grafstrom, R.C., and Wiman, K.G. (1997) Restoration of the growth suppression function of mutant $\mathrm{p} 53$ by a synthetic peptide derived from the $\mathrm{p} 53$ C-terminal domain. Nat. Med. 3, 632-638.

Sugrue, M.M., Shin, D.Y., Lee, S.W., and Aaronson, S.A. (1997) Wild-type p53 triggers a rapid senescence program in human tumor cells lacking functional p53. Proc. Natl. Acad. Sci. U.S.A. 94, 9648-9653.

Thornberry, N.A., and Lazebnik, Y. (1998) Caspases: Enemies within. Science 281, 1312-1316.

Van Meir, E.G., Kikuchi, T., Tada, M., Li, H., Diserens, A.C., Wojcik, B.E., Huang, H.J., Friedmann, T., de Tribolet, N., and Cavenee, W.K. (1994) Analysis of the p53 gene and its expression in human glioblastoma cells. Cancer Res. 54, 649-652.

Waga, S., Hannon, G.J., Beach, D., and Stillman, B. (1994) The p21 inhibitor of cyclin-dependent kinases controls DNA replication by interaction with PCNA. Nature 369, 574-578.

Yount, G.L., Haas-Kogan, D.A., Vidair, C.A., Haas, M., Dewey, W.C., and Israel, M.A. (1996) Cell cycle synchrony unmasks the influence of p53 function on radiosensitivity of human glioblastoma cells. Cancer Res. 56, 500-506.

Zhang, W., Shay, J.W., and Deisseroth, A. (1993) Inactive p53 mutants may enhance the transcriptional activity of wild-type p53. Cancer Res. 53, 4772-4775. 